\title{
Deoxyribonucleic Acid Base Composition of Acetic Acid Bacteria
}

\author{
BY J. DE LEY AND J. SCHELL \\ Laboratory for Microbiology, Faculty of Sciences, \\ State University, Gent, Belgium
}

(Received 27 March 1963)

\begin{abstract}
SUMMARY
The base composition of purified DNA from 28 strains of acetic acid bacteria was determined. Most strains of the genus Gluconobacter clustered closely together at $60 \cdot 6-63 \cdot 4 \%$ (guanine + cytosine) of total base. All strains of the Acetobacter aceti biotype lay within the range 55.4-64.0\% (guanine + cytosine). The close relationship and possible common phylogenetic origin of the genera Gluconobacter and Acetobacter is again stressed by these results. The base composition of DNA from acetic acid bacteria and from species of Pseudomonas was very similar, confirming the suspected close relationship between these groups. There is a noticeable agreement between the sequences of Acetobacter strains, arranged according to increasing $\%$ (guanine + cytosine) and arranged according to increasing enzymic equipment: strains with greater biochemical activity have on the whole also a higher \% (guanine + cytosine) in DNA. The range of the compositional distribution of DNA molecules is on the whole broader in Acetobacter than in Gluconobacter. The results corroborate previous conclusions that both biotypes contain clusters of strains without species differentiation. A comparison of the paper chromatographic analysis with the method of thermal denaturation ('melting point') for estimating base composition of DNA showed that the latter method was to be preferred in routine analysis because of its ease, rapidity and reproducibility.
\end{abstract}

\section{INTRODUCTION}

DNA base composition appears to be a promising new tool in bacterial taxonomy (Lee, Wahl \& Barbu, 1956; Belozersky \& Spirin, 1958; Lanni, 1960; Sueoka, 1961; Schildkraut, Marmur \& Doty, 1962; Marmur \& Doty, 1962; Marmur, Seaman \& Levine, 1963). The present knowledge in this field can be summarized as follows.

(1) Different 'strains' of the same well-established species have almost identical DNA base compositions. Thus, for seven strains of Escherichia coli, the molar content of guanine + cytosine $(\mathrm{G}+\mathrm{C})$ expressed as a percentage of the total base in the DNA was $50 \% \pm 0 \cdot 4$. (Marmur \& Doty, 1962). Different strains of $E$. coli had $50 \%$ $(\mathrm{G}+\mathrm{C})$, even when determined by different authors.

(2) Different 'species' which are known for morphological, physiological and other reasons to belong to the same genus, have identical or closely related $\%$ $(\mathrm{G}+\mathrm{C})$ values. This is well illustrated, for example, in the genera Escherichia, Salmonella, Clostridium and Hemophilus (Lee et al. 1956; Marmur \& Doty, 1962). Exceptions are believed to be indicative of wrong classification. For example, 
Catlin \& Cunningham (1961) found all the strains of Neisseria they examined to have $49 \cdot 5-51 \cdot 5 \%(G+C)$, except for $N$. catarrhalis, which had $40 \cdot 0-41 \cdot 3 \%$. They conclude that "the inclusion of "catarrhalis" strains in the genus Neisseria appears illogical from the evolutionary point of view.' The suspected divergency within Proteus was confirmed by the results of Falkow, Ryman \& Washington (1962), who found that $P$. morganii had a $50 \%(\mathrm{G}+\mathrm{C})$, whereas the other species had $39 \%$. On physiological and biochemical grounds $P$. morganii had previously been thought to be only remotely related to the other species 'vulgaris' and 'mirabilis' and a new genus Morganella had even been proposed for it (Fulton, 1943). The genus Bacillus offers another example where base composition tends to confirm the interpretation which was reached by quite different arguments. Base composition in Bacillus varies between 33 and $\mathbf{5 0} \%(\mathrm{G}+\mathrm{C})$; this is an unusually wide range for one genus. The explanation might be (De Ley, 1962) that Bacillus should not be considered a single genus, but a collection of genera or biotypes, which would form the bridge between the Enterobacteriaceae (about 50\% G +C) and the saccharolytic clostridia (about $27 \% \mathrm{G}+\mathrm{C}$ ). Bisset (1962) suggested that 'there is room for several genera in the family Bacillaceae'.

(3) Different genera, which are known or suspected for morphological, physiological, biochemical and other reasons to be closely related, also have base compositions which are very similar such as Escherichia, Salmonella and Shigella (Lee et al. 1956; Marmur \& Doty, 1962), Proteus and Providence (Falkow et al. 1962). Unrelated genera have widely different $\%(G+C)$ values, the range being from 25 to $75 \%(\mathrm{G}+\mathrm{C})$.

(4) If the mean $\%(G+C)$ of the DNA of two strains is different by $10 \%$, there are few DNA molecules of the same $(G+C)$ content common to both of them (Sueoka, 1961).

(5) Organisms with a closely related base composition are believed to be phylogenetically related (Sueoka, 1961) when they also display related morphological, physiological, biochemical and other characteristics.

However, up to now, the DNA base composition method has not been applied systematically to a wide set of strains of a group of bacteria other properties of which have been thoroughly investigated. The acetic acid bacteria seemed to be suitable objects for an application and test of the above conclusions. In view of the finding that Gluconobacter and Acetobacter each consist of a series of strains with a gradation of properties, it was proposed to regard all previous 'species' as variants within the biotypes Gluconobacter oxydans and Acetobacter aceti, which might phylogenetically be derived from the same common pool of ancestors (De Ley, 1961a). It was thus expected that the DNA base composition of Gluconobacter would be similar to that of Acetobacter, that the DNA base composition of all strains within each biotype would cluster in the same region, and that the base composition of acetic acid bacteria would be in the neighbourhood of that of Pseudomonas, namely $60-67 \%(\mathrm{G}+\mathrm{C})$, in view of their suspected close taxonomic relationship.

Two methods were used: (1) direct estimation of purine and pyrimidine bases after hydrolysis and paper chromatographic separation; (2) thermal denaturation ('melting point'). It was also the aim of the present work to compare the practicability of both methods for routine analysis. 


\section{METHODS}

Organisms. We used the same strains as described previously (De Ley, 1961a) and will adhere to the nomenclature proposed in that paper. In addition, we also used Acetobacter aceti (strains paradoxus $\mathrm{P} 1$ and $\mathrm{P} 2$ ) and $A$. aceti (strains peroxydans 3 and 4) obtained through the courtesy of Dr J. W. M. la Rivière (Laboratory of Microbiology, Delft, the Netherlands), Gluconobacter oxydans strain melanogenus 116 (courtesy of $\mathrm{Dr}$ A. H. Stouthamer, Laboratory of Microbiology, Utrecht, the Netherlands) and G. oxydans strain melanogenus 49 (courtesy of Mr M. R. Kimmitt, H. P. Sauce Ltd., Birmingham, England). Repeated plating and re-determination of the properties of the strains according to the criteria of Frateur (1950) and De Ley (1961a) assured that only pure cultures were used. Pseudomonas fluorescens CCEB 488 was obtained through the courtesy of Dr O. Lysenko (Institute of Biology, Prague); Agrobacterium tumefaciens through the courtesy of Dr M. Bernaerts (Ministry of Economic Affairs, Brussels) and the Escherichia coli was a National Collection of Type Cultures (Colindale, London, Great Britain; NCTC) strain.

Mass cultures. All strains of acetic acid bacteria were incubated at $30^{\circ}$ for 2 to 3 days on solid media in Roux flasks, except for the strains of 'peroxydans' and 'paradoxus', which needed 1 week. Strains of Gluconobacter and the 'mesoxydans' group of Acetobacter were grown on a medium containing $(\%, w / v): 10$, glucose; 3, $\mathrm{CaCO}_{3} ; 1$, Yeastex (Ned. Gist en Spiritusfabriek, Brugge, Belgium); 2.5, agar. Most strains of the 'oxydans' and 'peroxydans' groups of Acetobacter were grown on $\mathbf{1 . 5} \%$ malt extract (Difco), $0.5 \%$ Yeastex, $3 \%(\mathrm{v} / \mathrm{v})$ ethanol, $2.5 \%$ agar. $\boldsymbol{A}$. aceti (paradoxus) was grown on $\mathbf{5 0} \%$ (v/v) red wine, $0.5 \%$ Yeastex, $1 \%$ DL-lactate Ca salt, $2 \% \mathrm{CaCO}_{3}, \mathbf{2 \cdot 5} \%$ agar. Sometimes other media were used, e.g. with sorbitol instead of glucose. No differences in DNA base composition were then observed.

Pseudomonas fluorescens was incubated for one day at $30^{\circ}$ in a liquid medium with $\mathbf{0 . 5} \%$ peptone (Difco) $+\mathbf{0 . 2 5} \%$ Yeastex and with passage of sterile air. Agrobacterium was grown in Roux flasks on a medium with $1 \%$ Yeastex, $1 \%$ glucose, $2 \%$ $\mathrm{CaCO}_{3}$ and $2.5 \%$ agar for two days at $30^{\circ}$. Escherichia coli was grown for two days at $30^{\circ}$ in Roux flasks on $0.5 \%$ peptone, $0.25 \%$ Yeastex and $2.5 \%$ agar.

Estimation of DNA base composition by paper chromatography. Organisms were harvested and washed as previously described (De Ley, 1961a). The pellet was extracted according to the method of Smith \& Wyatt (1951). Two to three g. wet wt. living bacteria were suspended in $10 \mathrm{ml}$. $\mathrm{N}-\mathrm{NaOH}$ and incubated at $37^{\circ}$ for $20 \mathrm{hr}$. In some experiments the organisms were treated with $1 \% \mathrm{Na}$ lauryl sulphate before $\mathrm{NaOH}$ extraction. No significant difference in the final yield was observed. After the extraction the residue was centrifuged down in a Servall SS-1 at 13,000 $\mathrm{g}$ for $15 \mathrm{~min}$. The DNA was precipitated by adjusting to $\mathrm{pH} 4$ with acetic acid and adding one vol. of $95 \%(\mathrm{v} / \mathrm{v})$ ethanol in water. The precipitate was centrifuged down and dissolved in $10 \mathrm{ml}$. dilute $\mathrm{NaOH}$. Protein was removed by gel-formation with chloroform according to the method of Sevag, Lackman \& Smolens (1938). The solution was shaken with 0.25 vol. chloroform and $0 \cdot 1$ vol. octanol for $30 \mathrm{~min}$. and the chloroform and aqueous layers then separated by centrifugation at $2700 \mathrm{~g}$ for $15 \mathrm{~min}$. The upper aqueous layer was repeatedly treated with chloroform for $15 \mathrm{~min}$. and centrifuged until almost no protein was observed at the liquid/liquid interface. DNA was again precipitated with ethanol at $\mathrm{pH} 4$; the precipitate collected by 
centrifugation, redissolved in $10 \mathrm{ml}$. dilute $\mathrm{NaOH}$ and the amount of nucleic acid and protein determined by measuring the extinction at 260 and $280 \mathrm{~m} \mu$ according to Warburg \& Christian (1942). DNA was again precipitated with ethanol at pH 4 and dried in a vacuum desiccator. It was hydrolysed with $72 \%(\mathrm{v} / \mathrm{v})$ perchloric acid and the purines and pyrimidines of $10 \mu \mathrm{l}$. spots separated by paper chromatography with a mixture of $65 \%(\mathrm{v} / \mathrm{v})$ isopropanol $2 \mathrm{~N}$ with respect to $\mathrm{HCl}$, as the solvent (Wyatt, 1951). After separation the bases were detected on the chromatograms by the photographic method of Markham \& Smith (1949). The chromatograms were first dried overnight at room temperature. The source of ultraviolet radiation was a germicidal G.E. lamp; Gevaert Reflex Document paper was used for contact prints. The spots on the chromatograms were copied from the prints, cut out, eluted with $4 \mathrm{ml} .0 \cdot 1 \mathrm{~N}-\mathrm{HCl}$ (Wyatt, 1951) by standing for 15-20 hr. at $37^{\circ}$. Blanks of equal size were cut out at distances corresponding to the $\boldsymbol{R}_{F}$ value of the bases, from a strip of the same chromatogram, on which $10 \mu \mathrm{l}$. $2 \mathrm{~N}-\mathrm{HClO}_{4}$ had been spotted between triplicate sample spots. The eluates of the bases were read against the corresponding blanks in a Beckman spectrophotometer (model DU) at the wavelengths indicated by Vischer \& Chargaff (1948), except for cytosine, for which $274 \mathrm{~m} \mu$ was used since this gave more reproducible results. The amount of each of the bases was calculated from the difference $\Delta$ between the extinction at the absorption peak and at $290 \mathrm{~m} \mu$. For test solutions containing $10 \mu \mathrm{g}$. bases $/ \mathrm{ml}$. $0 \cdot 1 \mathrm{~N}-\mathrm{HCl} \Delta$ is : $\Delta_{\text {adenine }}=E_{262 \cdot 5}-E_{290}=0.900 ; \Delta_{\text {guanine }}=E_{249}-E_{290}=0 \cdot 475 ; \Delta_{\text {thymine }}$ $=E_{264.5}-E_{290}=0.545 ; \Delta_{\text {cytosine }}=E_{274}-E_{290}=0.458 . \Delta$ for cytosine was determined with a pure sample from Calbiochem (3625 Medford Street, Los Angeles 63, California, U.S.A.)

Estimation of DNA base composition by thermal denaturation. DNA was isolated according to the method of Marmur (1961). Thermal denaturation was followed at $260 \mathrm{~m} \mu$ in a Beckman spectrophotometer (model DU) as described by Marmur \& Doty (1962). To protect the photocell and the slit of the monochromator against excessive heating, which would result in inaccurate readings, it was found advantageous to use the following arrangement. The cell holder compartment was flanked at each side by the following set up: first two thermospacers for the circulating hot water from a Haake Ultra-Thermostat NB, followed by a $5 \mathrm{~mm}$ layer of cork and finally another thermospacer through which passed dropwise a current of tap water at $12^{\circ}$. To prevent traces of water vapour reaching the photocell (which would again result in erratic readings) a suitable well was machined into the side of the cell-holder compartment, which faced the photocell, and a circular quartz window was glued into the opening. The cell-holder compartment itself was insulated on all sides at the outside by cork. Tubing between the circulating water bath and the thermospacers has to be as short as possible and insulated by either plastic or asbestos. In this way the difference in temperature between the liquid in the cuvettes and the bath did not exceed $1 \cdot 2^{\circ}$. The circulating water contained either $\mathbf{2 5} \%$ ethyleneglycol or $\mathbf{3 0} \%$ glycerol. The temperature in the cell-holder compartment was measured in a cuvette, containing water, tightly covered with a plastic cover, through which passed a calibrated thermometer. A suitable hole was drilled through the compartment cover. The thermostated cell holder compartment is schematically represented in Fig. 1. Blanks and the samples were measured in quartz cuvettes with ground glass stoppers. The $\boldsymbol{T}_{m}$ values were determined graphi- 
cally according to Marmur \& Doty (1962), $T_{m}$ being the temperature at the midpoint of the transition of the absorbance-temperature curve.

Estimation of the range of base composition distribution of DNA. Assuming that the distribution of the compositional distribution of DNA molecules around $T_{m}$ was Gaussian, the standard deviation $\sigma$ of the distribution, expressed as $\%(\mathbf{G}+\mathbf{C})$ and corrected for the natural transition width of adenine-thymine DNA, was determined for each strain from the absorbance-temperature curves according to Doty, Marmur \& Sueoka (1959). The mean \% $(G+C)$ was calculated with Marmur $\&$ Doty's (1962) formula: \% $(\mathrm{G}+\mathrm{C})=\left(T_{m}-69 \cdot 3\right) / 0 \cdot 41$. The Gaussian distribution around the mean $\%(\mathrm{G}+\mathrm{C})$ was calculated with the equation $y=1 /(\sigma \sqrt{2} \pi)$ $\exp \left(-x^{2} / 2 \sigma^{2}\right)$, in which $x$ was expressed as $\%(\mathrm{G}+\mathrm{C})$ around the mean. The results are represented graphically in Figs. 4 and 5 . The ratio of the area under the $y$ curve in any $\%(\mathbf{G}+\mathbf{C})$ interval to the total area represents the fraction of the DNA molecules within this $\%(\mathrm{G}+\mathrm{C})$ range of the total number of DNA molecules.

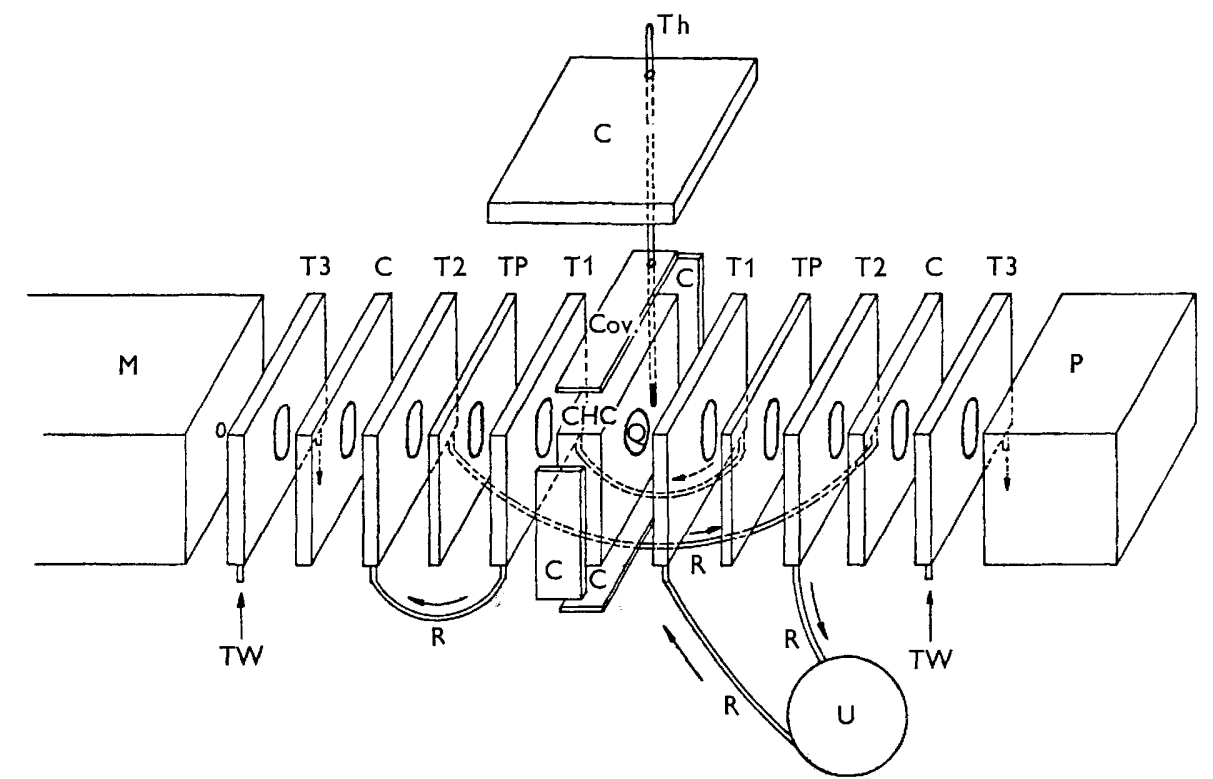

Fig. 1. Details of the thermostated cell holder compartment. M, Beckman monochromator (model DU); T3, thermospacer with circulating tap water (TW) at $12^{\circ}$; C, cork; T2 and T1, thermospacers with circulating hot water through insulated rubber tubing (R) from the ultra thermostat (U); TP, thermospacer plate; CHC, cell holder compartment with glued-in quartz window (Q); Cov., cell holder compartment cover; Th, calibrated thermometer; $P$, phototube housing from the Beckman spectrophotometer (model DU).

\section{RESULTS}

The results are summarized in Table 1 . The $T_{m}$ value is an average of at least two determinations; $T_{m}$ values were in most cases reproducible to within $\mathbf{0} \cdot \mathbf{1}^{\circ}$, exceptionally to $0 \cdot 15^{\circ}$. $\sigma$ was usually reproducible to about $0 \cdot 25 \%(\mathrm{G}+\mathrm{C})$. The values given for the paper chromatographic method represent the average values of at least six estimations from two different extractions. The reproducibility of this method can be seen in Table 2, which illustrates the actual results obtained with three strains. The mean deviation on the ratio $(A+T) /(G+C)$ was $2 \cdot 8,2 \cdot 9$ and 
$3.7 \%$ for these three examples, which is the common range of deviation in quantitative paper chromatographic extractions. When the base composition, expressed as $\%(\mathbf{G}+\mathbf{C})$, as determined by the paper chromatographic method, was plotted against the $T_{m}$ values of the same strains (see Fig. 2), the result was in good agreement with Marmur \& Doty's (1962) formula $\%(G+C)=\left(T_{m}-69 \cdot 3\right) / 0 \cdot 41$. Two examples of thermal denaturation curves are given in Fig. 3. The compositional distribution of DNA molecules is represented in Figs. 4 and 5.

Table 1. Base composition, expressed as \% $(G+C)$, 'melting points' $T_{m}$ values and standard deviation $\sigma$ of the compositional distribution about the mean $\%(G+C)$ of purified DNA of various acetic acid bacteria

\begin{tabular}{|c|c|c|c|c|}
\hline \multirow[b]{2}{*}{ Strain } & \multirow{2}{*}{$\begin{array}{c}\text { (Methods : see text } \\
\text { Paper } \\
\text { chromato- } \\
\text { graphic } \\
\text { method } \\
\%(\mathrm{G}+\mathrm{C})\end{array}$} & \multicolumn{3}{|c|}{ Thermal denaturation method } \\
\hline & & $T_{m}$ & $\%(\mathbf{G}+\mathbf{C})$ & $\sigma$ \\
\hline \multicolumn{5}{|l|}{ Biotype } \\
\hline \multicolumn{5}{|l|}{ Acetobacter aceti } \\
\hline liquefaciens 20 & $65 \cdot 4$ & $95 \cdot 6^{\circ}$ & $64 \cdot 0$ & $1 \cdot 5$ \\
\hline xylinum 25 & - & $95 \cdot 1^{\circ}$ & $62 \cdot 8$ & $\mathbf{2 \cdot 6}$ \\
\hline xylinoides 4940 & $\ldots$ & $94 \cdot 95^{\circ}$ & $62 \cdot 4$ & $\mathbf{1 \cdot 5}$ \\
\hline estunensis $\mathbf{E}$ & - & $94 \cdot 85^{\circ}$ & $62 \cdot 2$ & $1 \cdot 1$ \\
\hline xylinum 8747 & $61 \cdot 1$ & $94 \cdot 25^{\circ}$ & $60 \cdot 7$ & $2 \cdot 25$ \\
\hline mesoxydans var. saccharovorans 4 & $61 \cdot 0$ & $94 \cdot 2^{\circ}$ & $60 \cdot 6$ & $1 \cdot 6$ \\
\hline pasteurianus 11 & - & $93 \cdot 85^{\circ}$ & $59 \cdot 8$ & $1 \cdot 75$ \\
\hline aceti Ch31 & $59 \cdot 5$ & $93 \cdot 8^{\circ}$ & $59 \cdot 6$ & $1 \cdot 6$ \\
\hline aceti var. muciparus $\mathbf{5}$ & - & $93 \cdot 75^{\circ}$ & $59 \cdot 5$ & $1 \cdot 5$ \\
\hline mobilis 6428 & $58 \cdot 8$ & $93 \cdot 5^{\circ}$ & $58 \cdot 9$ & $1 \cdot 25$ \\
\hline vini acetati 4939 & - & $92.9^{\circ}$ & $57 \cdot 4$ & $1 \cdot 2$ \\
\hline rancens 15 & - & $92 \cdot 4^{\circ}$ & $56 \cdot 2$ & $1 \cdot 1$ \\
\hline cerinus var. rosiensis 22 & $56 \cdot 5$ & $92 \cdot 2^{\circ}$ & $55 \cdot 7$ & $1 \cdot 75$ \\
\hline paradoxus $\mathbf{P} 1$ & - & $92 \cdot 2^{\circ}$ & $55 \cdot 7$ & $1 \cdot 1$ \\
\hline rancens $23 \mathrm{kl}+$ & - & $92 \cdot 1^{\circ}$ & $55 \cdot 4$ & $0 \cdot 9$ \\
\hline paradoxus $\mathbf{P 2}$ & 一 & $92 \cdot 1^{\circ}$ & $55 \cdot 4$ & $1 \cdot 25$ \\
\hline peroxydans $\mathbf{3}$ & - & $95 \cdot 35^{\circ}$ & $63 \cdot 4$ & $1 \cdot 5$ \\
\hline peroxydans 4 & - & $95 \cdot 35^{\circ}$ & $63 \cdot 4$ & $1 \cdot 1$ \\
\hline peroxydans 8618 & $61 \cdot 0$ & $95 \cdot 0^{\circ}$ & $62 \cdot 5$ & 一 \\
\hline \multicolumn{5}{|l|}{ Gluconobacter oxydans } \\
\hline viscosus 8131 & $62 \cdot 1$ & $95 \cdot 35^{\circ}$ & $63 \cdot 4$ & $0 \cdot 56$ \\
\hline suboxydans 26 & $61 \cdot 0$ & $94.85^{\circ}$ & $62 \cdot 2$ & 0.5 \\
\hline capsulatus 4943 & $61 \cdot 3$ & $94.75^{\circ}$ & 61.9 & 0.5 \\
\hline suboxydans $\mathbf{3 7 3 4}$ & - & $94 \cdot 65^{\circ}$ & $61 \cdot 7$ & $0 \cdot 63$ \\
\hline gluconicum 4739 & - & $94.55^{\circ}$ & $61 \cdot 4$ & $0 \cdot 38$ \\
\hline melanogenus 49 & - & $94 \cdot 4^{\circ}$ & $61 \cdot 1$ & $1 \cdot 25$ \\
\hline melanogenus 8086 & $61 \cdot 0$ & $94 \cdot 2^{\circ}$ & $60 \cdot 6$ & $1 \cdot 06$ \\
\hline melanogenus 116 & - & $\mathbf{9 4} \cdot \mathbf{2}^{\circ}$ & $60 \cdot 6$ & $0 \cdot 87$ \\
\hline suboxydans $\mathrm{sU}$ & $58 \cdot 1$ & $92 \cdot 8^{\circ}$ & $57 \cdot 2$ & $0 \cdot 38$ \\
\hline
\end{tabular}

Three other bacteria were included as controls of the methods. Pseudomonas fuorescens 488 had a DNA base composition of $59.5 \%(G+C)$, determined by paper chromatography, which is in good agreement with reported values for Pseudomonas in the literature (Lee et al. 1956; Marmur \& Doty, 1962). Agrobacterium tumefaciens DNA had 58.8 \% $(\mathrm{G}+\mathrm{C})$, also determined by paper chromatography. For other strains 58.2 and 58.8\% have been reported (Lee et al. 1956). For Escherichia coli a $(\mathrm{G}+\mathrm{C}) \%$ value of $\mathbf{5 0 \cdot 0}$ was calculated from the $\boldsymbol{T}_{m}$ value. 
Table 2. Reproducibility of the chromatographic method for molar base composition determination

(All the values given represent the average of three spots from one chromatogram. Methods: see text. Abbreviations: $\mathbf{A}=$ adenine; $\mathbf{T}=$ thymine; $\mathbf{G}=$ guanine; $\mathbf{C}=$ cytosine. As an evaluation of the method, the values $A / T, G / C$ and $A+G / T+C$ (which ought to be equal to 1 ), as well as $A / G$ and $T / C$ (which ought to be equal), are presented.)

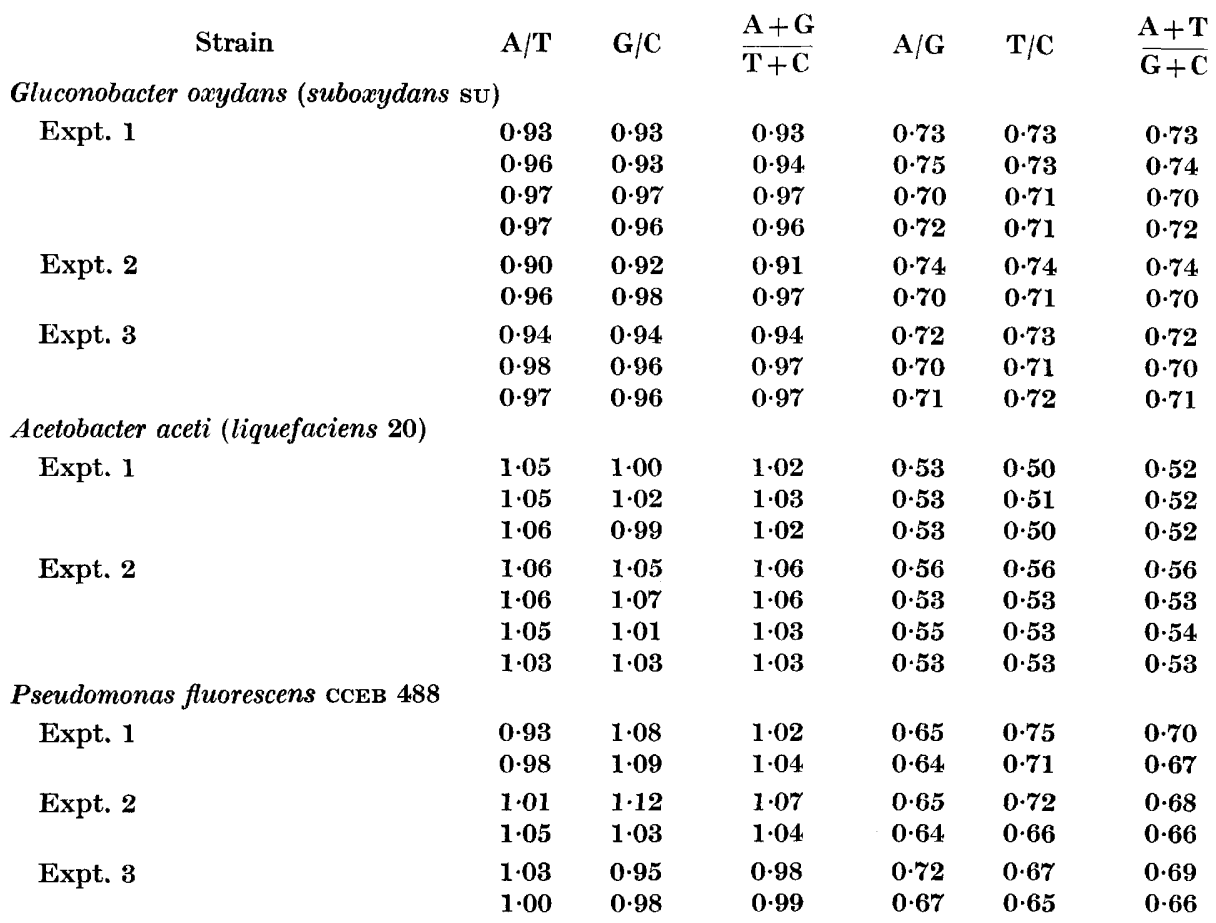

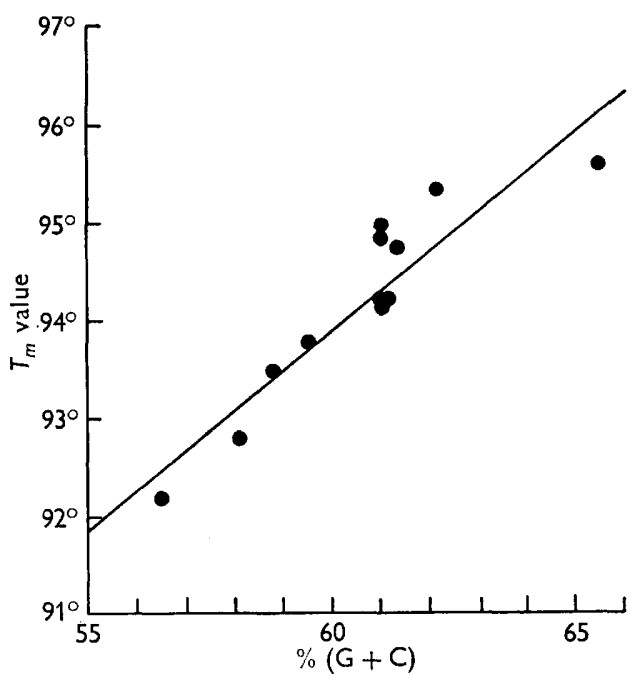

Fig. 2. Relationship between the 'melting point' $T_{m}$, determined by thermal denaturation, and the base composition $\%(G+C)$ determined by paper chromatography, of purified DNA from several acetic acid bacteria. The numbers are taken from Table 1 . The curve was drawn from Marmur \& Doty's formula $T_{m}=0 \cdot 41(\% \mathrm{G}+\mathrm{C})+69 \cdot 3$. 


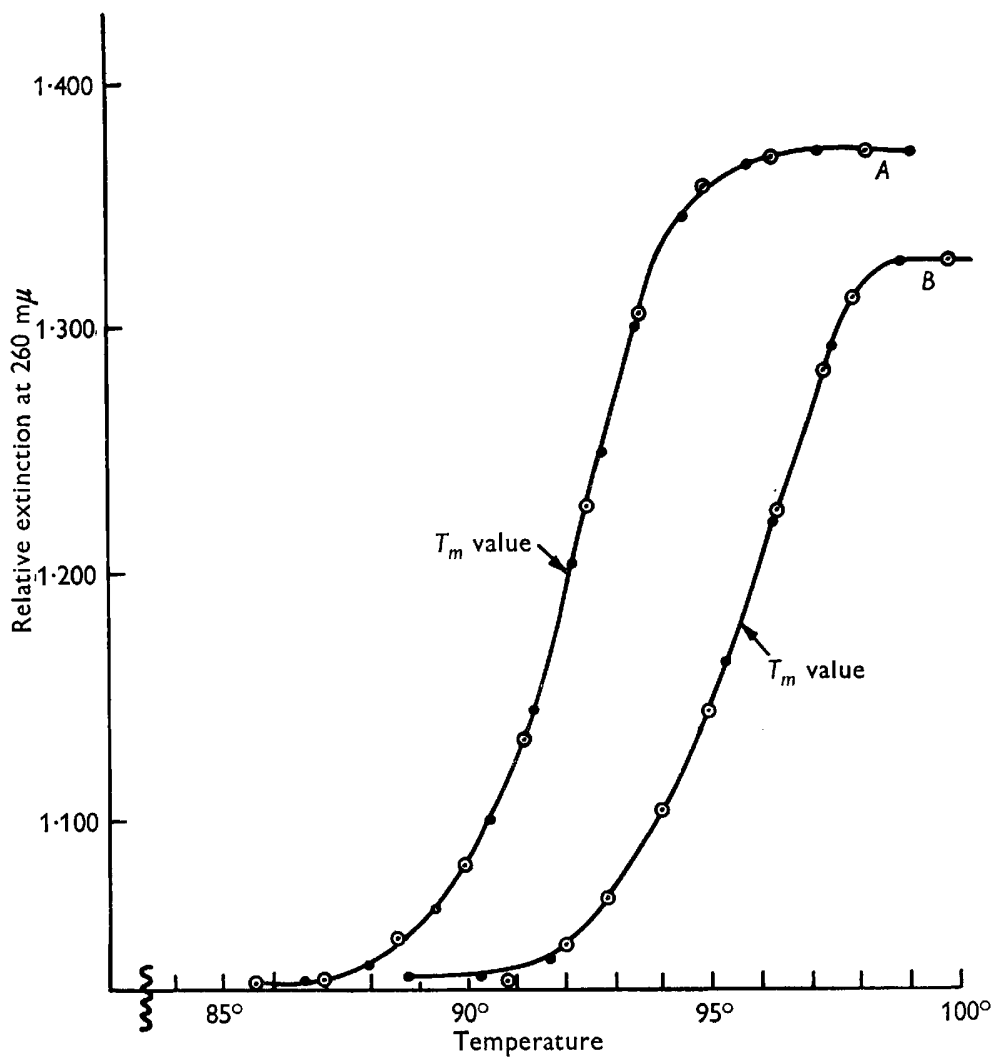

Fig. 3. Thermal denaturation curves of purified DNA of two strains of acetic acid bacteria. The examples were selected to represent the strains with the lowest $T_{m}$ value (curve $A, A$ cetobacter aceti, 'paradoxus' P2) and with the highest $\boldsymbol{T}_{m}$ value (curve $B$, A. aceti, 'liquefaciens' 20). All other strains of Acetobacter and Gluconobacter had $T_{m}$ values within these limits. Each curve is the result of two different estimations. The results are expressed as relative extinction at $260 \mathrm{~m} \mu$, being the ratio extinction at temp. $t$ /extinction at $25^{\circ}$.

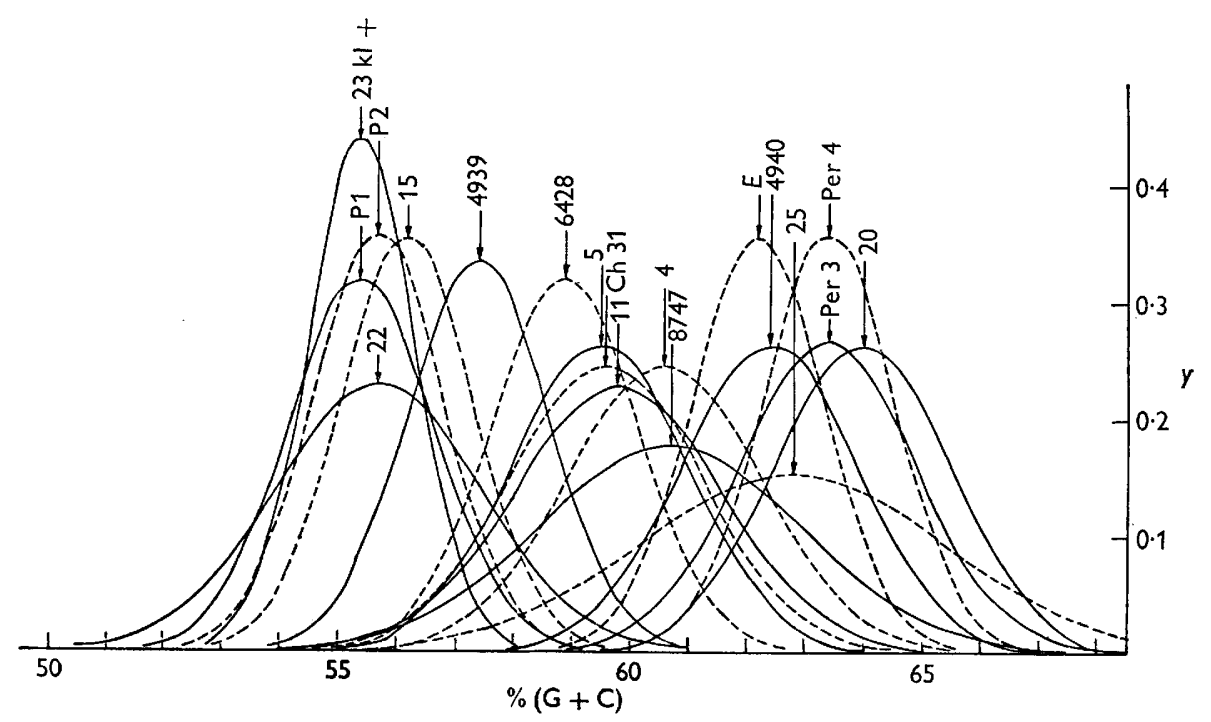

Fig. 4. Approximation of the compositional distribution of the DNA molecules of strains of Acetobacter. The symbols pointing to each curve are the strain numbers (see Table 1). The position of the arrows indicates the mean $\%(G+C)$. The curves were calculated as described in the text. 


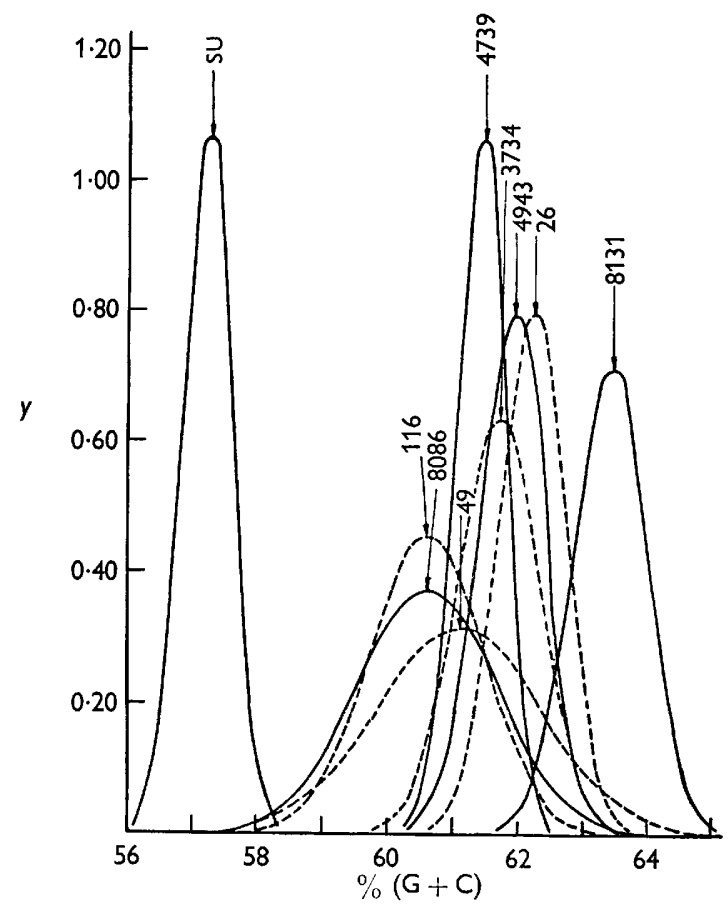

Fig. 5. Approximation of the compositional distribution of the DNA molecules of strains of Gluconobacter. The symbols pointing to each curve are the strain numbers (see Table 1). The position of the arrows indicates the mean $\%(\mathrm{G}+\mathrm{C})$. The curves were calculated as described in the text.

\section{DISCUSSION}

All Acetobacter strains have base compositions of $(\mathrm{G}+\mathrm{C})$ between $\mathbf{5 5 \cdot 4} \%$ (strain 'paradoxus' P2, 'rancens' $23 \mathrm{kl}+$ ) and $64.0 \%$ (strain 'liquefaciens' 20 ). Nearly all Gluconobacter strains lay in a narrow cluster from $60.6 \%$ (strain 'melanogenus' 116) to $63 \cdot 4 \%$ (strain 'viscosus' 8131 ). Strain 'suboxydans' SU with $57 \cdot 2 \%$ was the only one to be somewhat removed from the central cluster of Gluconobacter (Table 1; Fig. 5). These data are in agreement with the conclusion of De Ley (1961 $a$ ) that each biotype Acetobacter aceti and Gluconobacter oxydans can be regarded as a cluster of strains, without inner sharp breaks, thus making species differentiation unnecessary. This is also clearly illustrated in Figs. 4 and 5 by the continuously overlapping curves of the compositional distribution. Incidentally, the range of the distribution of DNA molecules of each strain is broader in Acetobacter (average $\sigma$ 1.5) than in Gluconobacter (average $\sigma$ for the melanogenus strains: 1.06; for the other strains: $0 \cdot 5$ ).

On the basis of physiological, biochemical and enzymic data De Ley (1961a) noted that the strains of the Acetobacter aceti biotype could be arranged in a smooth gradation from the most complex one to the one with the poorest enzymic equipment. A comparison of the sequence of Acetobacter strains of Table 1 with the sequence of Fig. 5 of De Ley's (1961 $a$ ) paper shows a noticeable agreement: strains with greater biochemical activities have on the whole also a higher $\%(G+C)$. (De Ley \& Schell, 1962, drew attention to the fact that the strain 'liquefaciens' 20 has to be removed 
from Gluconobacter and belongs in the biotype Acetobacter, where it is the most complex representative.) In Gluconobacter the base compositions are so close together that they cannot be arranged in a sequence of statistical significance. In Table 1 and Figs. 4 and 5, some strains are not where they would be expected according to their position in the biochemical sequence. This holds for 'estunensis', 'pasteurianus' 11, 'suboxydans' su and 'peroxydans' 3, 4 and 8618. However, it ought not to be expected that both sequences would agree completely. Indeed, the $\%(\mathrm{G}+\mathrm{C})$ range encompasses the complete genotype and includes all properties, whereas the biochemical sequence was based mainly on carbohydrate metabolism. It might be that the strains 'estunensis', 'pasteurianus' 11 and 'suboxydans'su possess or lack some properties which have so far escaped examination. The peroxydans strains were expected to have very low base compositions in the vicinity of 'paradoxus' and 'rancens' in view of their biochemical similarities with these strains. The base composition of the 'peroxydans' strains is unexpectedly high. Fig. 4 shows that the 'peroxydans' strains have in fact only very few DNA molecules in common with the 'paradoxus' and 'rancens' strains. A similar situation holds for strain 'suboxydans' su, which is morphologically, physiologically and biochemically nearly indistinguishable from strain suboxydans 26 , but nevertheless appears to have very few DNA molecules in common with it. Further work on the finer details of the DNA molecules in relation to the taxonomic position of these strains will be required.

As expected, Gluconobacter and Acetobacter strains have DNA with base compositions in the same range. These results support the hypothesis (De Ley, 1961a) which proposes that Gluconobacter and Acetobacter may have originated from a common pool of ancestors.

The DNA base compositions of the acetic acid bacteria are in the same range as those for Pseudomonas, which extend from 60 to $67 \%(\mathrm{G}+\mathrm{C})($ Lee et al. 1956; Marmur \& Doty, 1962). This stresses once more the suspected close relationship between the pseudomonads and the acetic acid bacteria. Phenotypically they have several features in common (Stanier, 1947; for a review see De Ley, $1961 b$ ). The similarity in the base compositions of the DNA molecules of both groups of bacteria also points to a possible genotypic relationship. It seems not unlikely that these bacteria derive from a common phylogenetic origin. The comparison between the methods of paper chromatography and thermal denaturation for the estimation of DNA base compositions for routine analysis showed that the latter procedure was to be preferred; it is easier, faster, less elaborate and yields more reproducible results.

The senior author (J.D.L.) is indebted to the Belgian Government and the Nationale Raad voor Wetenschapsbeleid for a grant from the Collectief Fundamenteel Onderzoek. 


\section{REFERENCES}

Belozersky, A. N. \& Spirin, A. S. (1958). A correlation between the compositions of deoxyribonucleic and ribonucleic acids. Nature, Lond. 182, 111.

Bisset, K. A. (1962). The phylogenetic concept in bacterial taxonomy. Symp. Soc. gen. Microbiol. 12, 361.

Catlin, B. W. \& Cunningham, L. S. (1961). Transforming activities and base contents of deoxyribonucleate preparations from various Neisseriae. J. gen. Microbiol. 26, 303.

De Ley, J. (1961a). Comparative carbohydrate metabolism and a proposal for a phylogenetic relationship of the acetic acid bacteria. J. gen. Microbiol. 24, 31 .

DE LEY, J. (1961b). Comparative carbohydrate metabolism and localisation of enzymes in Pseudomonas and related bacteria. J. appl. Bact. 23, 400.

DE LEY, J. (1962). Comparative biochemistry and enzymology in bacterial classification. Symp. Soc. gen. Microbiol. 12, 164.

De LeY, J. \& SCheLI, J. (1962). Lactate and pyruvate catabolism in acetic acid bacteria. J. gen. Microbiol. 29, 589.

Doty, P., Marmur, J. \& Sueoka, N. (1959). The heterogeneity in properties and functioning of deoxyribonucleic acids. Brookhaven Symp. Biol. no. 12, 1.

Falkow, S., Ryman, I. R. \& Washington, O. (1962). DNA base composition of Proteus and Providence organisms. J. Bact. 83, 1318.

Frateur, J. (1950). Essai sur la systématique des Acétobacters. Cellule, 53, 287.

Fulton, M. (1943). The identity of Bacterium columbensis Castellani. J. Bact. 46, 79.

LANNI, F. (1960). Genetic significance of microbial DNA composition. Perspectives in Biology and Medicine, 3, 418.

LEE, K. Y., WAHL, R. \& BARBU, E. (1956). Contenu en base puriques et pyrimidiques des acides désoxyribonucléiques des bactéries. Ann. Inst. Pasteur, 91, 212.

Markham, R. \& Smith, J. D. (1949). Chromatographic studies of nucleic acids. Biochem. $J .45,294$.

MARMUR, J. (1961). A procedure for the isolation of deoxyribonucleic acid from microorganisms. J. mol. Biol. 3, 208.

Marmur, J. \& Doty, P. (1962). Determination of the base composition of deoxyribonucleic acid from its thermal denaturation temperature. J. mol. Biol. 5, 109.

Marmur, J., Seaman, E. \& Levine, J. (1963). Interspecific transformation in Bacillus. J. Bact. 85, 461.

Schildkraut, C. L., Marmur, J. \& Doty, P. (1962). Determination of the base composition of deoxyribonucleic acid from its buoyant density in CsCl. J. mol. Biol. 4, 430.

Sevag, M. G., Lackman, D. B. \& Smolens, J. (1938). The isolation of the components of streptococcal nucleoproteins in serologically active form. J. biol. Chem. 124, 425 .

Smith, J. D. \& WyatT, G. R. (1951). The composition of some microbial deoxypentose nucleic acids. Biochem. J. 49, 144.

STAnier, R. Y. (1947). Acetic acid production from ethanol by fluorescent Pseudomonads. J. Bact. 54, 191.

SuEora, N. (1961). Variation and heterogeneity of base composition of deoxyribonucleic acids: a compilation of old and new data. J. mol. Biol. 3, 31.

Vischer, E. \& Chargaff, E. (1948). The separation and quantitative estimation of purines and pyrimidines in minute amounts. J. biol. Chem. 176, 703.

WYатT, G. R. (1951). The purine and pyrimidine composition of deoxypentose-nucleic acids. Biochem. $J$. 48, 584.

WARBURG, O. \& Christian, W. (1942). Isolierung und Kristallisation des Gärungsferments Enolase. Biochem. Z. 310, 384. 